\title{
Efficacy of Anti-PD1/PD-L1 Therapy (IO) in KRAS Mutant Non-small Cell Lung Cancer Patients: A Retrospective Analysis
}

\author{
LETIZIA GIANONCELLI ${ }^{1}$, GIANLUCA SPITALERI ${ }^{1}$, ANTONIO PASSARO $^{1}$, DAVIDE RADICE $^{2}$, \\ CATERINA FUMAGALLI ${ }^{3}$, ESTER DEL SIGNORE ${ }^{1}$, VALERIA STATI ${ }^{1}$, CHIARA MATILDE CATANIA $^{1}$, \\ ELENA GUERINI-ROCCO ${ }^{3}$, MASSIMO BARBERIS $^{3}$ and FILIPPO DE MARINIS ${ }^{1}$ \\ ${ }^{1}$ Division of Thoracic Oncology, European Institute of Oncology, IRCCS, Milan, Italy; \\ ${ }^{2}$ Division of Epidemiology and Biostatistics European Institute of Oncology, IRCCS, Milan, Italy; \\ ${ }^{3}$ Division of Pathology \& Laboratory Medicine, European Institute of Oncology, IRCCS, Milan, Italy
}

\begin{abstract}
Background/Aim: The role of anti-PD1/PD-L1 therapy (IO) in NSCLC harboring driver mutations is questionable. This study aimed to examine the efficacy of IO in patients with non-small cell lung cancer (NSCLC) with a KRAS mutation $\left(K_{R A S}^{+}\right)$. Patients and Methods: We retrospectively identified NSCLC patients harboring KRAS mutation treated with $I O$ in our Institution. We analyzed the results in comparison to non-KRAS patients. Results: Among 328 consecutive KRAS ${ }^{+}$NSCLC patients, 43 (13.1\%) received $I O$ in our Institution. In parallel 117 non-KRAS NSCLC patients treated with IO were selected for comparison. The baseline characteristics were similar between the two groups. No significant difference was observed between KRAS ${ }^{+}$and non-KRAS patients in terms of mPFS (4.6 vs. 3.3 months, $p=0.58$ ) or OS (8.1 vs. 13.0 months, $p=0.38$ ). Conclusion: KRAS mutations seem to be irrelevant for selecting patients for IO that could be therefore considered an effective therapy for NSCLC patients, independently of KRAS status.
\end{abstract}

The identification of oncogenic drivers has dramatically changed the therapeutic landscape of non-small cell lung cancer (NSCLC). KRAS, with a prevalence of $22-30 \%$ (1-3) represents the most frequent oncogene mutation in NSCLC, but it still fails to be druggable. To date, chemotherapy with platinum-based regimen remains the treatment backbone for $\mathrm{KRAS}^{+}$NSCLC patients (4). Most recently, the introduction of immunotherapy represented a paradigm shift in the treatment of NSCLC without any clinically actionable

Correspondence to: Letizia Gianoncelli, MD, Division of Thoracic Oncology, European Institute of Oncology, IRCCS, Via Ripamonti 435, 20141 Milan, Italy. Tel: +39 0257489482, e-mail: Letizia.gianoncelli@ieo.it

Key Words: KRAS, NSCLC, anti-PDI/PD-L1 therapy, immunotherapy. mutations (5). Of note, not all patients benefit from immunotherapy, but neither PD-L1 nor TMB proved to be an optimal predictor of IO efficacy (6-8). For this reason, the identification of other potential biomarkers that could predict clinical response or resistance to immunotherapy is crucial. The role of IO in the presence of known driver mutation is now under investigation, but no definitive data are available. Some preliminary results based on subgroup or retrospective analyses suggest the ineffectiveness of IO in disease with predictive biomarkers, such as EGFR, ALK, ROS1 or MET (9). In this regard, KRAS-mutant tumors have been considered an attractive target for immunotherapy, considering the association with smoke, the elevated level of PDL1 expression, the high tumor mutational burden, and the proven abundance of T-cell infiltrating lymphocytes. Despite the fact that, in the Checkmate 057 study (10), a potential advantage in mutated KRAS compared to other populations has been suggested, in other studies with IO (11-13) this benefit was not statistically significant. In the context in which there is no evidence originating from prospective trials, data derived from real-life experience can provide useful information for clinical practice. Our retrospective study was designed to compare clinical outcomes in KRAS ${ }^{+}$ $v s$. non-KRAS patients, treated routinely with IO.

\section{Patients and Methods}

Patient selection. Patients with stage IV NSCLC harboring KRAS mutation $\left(\mathrm{KRAS}^{+}\right)$treated with IO in our Institution between 2016 and 2018 were retrospectively identified by electronic medical record review. In parallel, patients treated with IO in the same period for stage IV NSCLC without KRAS mutation (non-KRAS) were selected for comparison. All patients provided written informed consent for the collection of demographic, clinical, radiological and molecular data. The study was conducted in accordance with the principles of good clinical practice, and Institutional review board and Ethics committee approval was obtained before the study initiation. 
Study design. In this retrospective cohort study, baseline demographic, clinical, and pathological characteristics were collected. In both $\mathrm{KRAS}^{+}$and non-KRAS groups, tumor response, OS and progressionfree survival (PFS) were assessed and compared. OS was calculated from the date of IO initiation until death from any cause; the outcome was censored if a patient was still alive at the time of last follow-up. PFS was calculated from the date of IO initiation until disease progression as defined by Response Evaluation Criteria In Solid Tumors, version 1.1 (RECIST 1.1) or death whichever comes first; the outcome was censored if a patient was still alive without known progression of disease at the time of last follow-up.

Molecular analysis and PD-L1 expression. Representative formalinfixed paraffin-embedded (FFPE) tissue blocks were used for the analyses of KRAS mutational status and PD-L1 immunohistochemical expression, as previously reported (14-16). Depending on the time of request, mutational analysis of KRAS was assessed either by Sanger Sequencing (14) or by Next-Generation Sequencing (NGS) (15). In detail, 19 cases were screened by Sanger Sequencing using BigDye Terminator chemistry and evaluated on 3500D x Genetic Analyzer (Applied Biosystems, Foster City, CA, USA). Twenty-four cases were subjected to targeted NGS analysis using the CE-IVD Oncomine Solid Tumour DNA kit (ThermoFisher, Waltham, MA, USA) that allowed the simultaneous evaluation of the mutational status of 22 genes, including KRAS. Sequencing was performed on Ion S5 System (ThermoFisher, Waltham, MA, USA) and the data were analyzed using the Ion Reporter Analysis software. All the patients enrolled in the present study were EGFR- and ALK-negative (wild type). PD-L1 expression was assessed on tumor cells using the immuno-histochemistry assay CE-IVD PD-L1 IHC 22C3 pharmDx with the Agilent-Dako 22C3 clone developed on the Dako Autostainer Link 48 (Agilent Technologies, Santa Clara, CA, USA) as previously described (16).

Statistical analysis. The patient's characteristics were summarized and tabulated against the KRAS mutation status either by count and percent for categorical variables or count, mean and Interquartile Range (IQR) for continuous variables. The median follow-up was estimated by the inverted Kaplan-Meier method. Univariate hazard ratios (HR) for the OS and PFS were estimated using the Cox regression model, estimates were tabulated alongside the $95 \%$ confidence interval (95\% CI). A multivariable Cox regression model was run in order to adjust the KRAS OS HR estimate by the Eastern Cooperative Oncology Group Performance Status (ECOG-PS). A multivariable competing risk Cox regression model including the KRAS status and the ECOG-PS was also run in order to estimate the HR for the progressive disease, death entered the model as a competing event, progressive disease was the event of interest. Between group $\left(\mathrm{KRAS}^{+} v s\right.$. non-KRAS) categorical variables comparison were done using the Fisher's exact test, the unpaired $t$-test or two-sample Wilcoxon test were used for continuous variables as appropriate. All tests were two-tailed and considered significant at the $5 \%$ level. All analyses were performed using SAS 9.4 (Cary, NC, USA).

\section{Results}

Demographics and clinical patient characteristics. Between 2016 and 2018 a total of 328 consecutive patients with $\mathrm{KRAS}^{+}$ NSCLC were identified, of them $43(13.1 \%)$ received IO for stage IV NSCLC. In 25 cases (58.1\%) NGS was available. Furthermore, 117 patients without KRAS mutation treated with
IO for the same indication were selected. Table I depicts the main patient characteristics. The baseline characteristics were similar between the two groups, however, the percentage of former/current smokers was significantly higher in the KRAS ${ }^{+}$ patients (93\% vs. 77.8\%, $p=0.04)$, as well as the percentage of patients with brain metastasis $(30.2 \%$ vs. $15.4 \%, p=0.04)$. Furthermore, $\mathrm{KRAS}^{+}$patients have two or more co-morbidities in a higher percentage of cases, in comparison with non-KRAS patients $(20.9 \%$ vs. $8.5 \%, p=0.001)$. Fourteen $\mathrm{KRAS}^{+}$patients were treated with IO in first-line $(32.6 \%)$. Similarly, 30 nonKRAS patients $(25.6 \%)$ received IO as first-line. Between the 10 subtypes of KRAS mutation identified in our cohort, G12C was the commonest $(17,46.0 \%)$. Between $\mathrm{KRAS}^{+}$patients, 10 $(23.3 \%)$ had co-occurring gene mutations.

Tumor response. Concerning tumor response, 41 and 88 patients were assessed for response in $\mathrm{KRAS}^{+}$and nonKRAS groups, respectively. No significant difference has been observed between $\mathrm{KRAS}^{+}$and non-KRAS patients in terms of ORR (19.5 vs. 36.4\%, $p=0.07)$ and DCR (53.7 vs. $55.7 \%, p=0.85)$, as illustrated in Table II.

Patient survival. The median follow-up time since IO initiation was 16.8 months for all patients, 18.5 months for $\mathrm{KRAS}^{+}$and 15.4 months for non-KRAS patients $(p=0.53)$. At the time of survival analysis, as illustrated in Figure 1A, the mPFS was 4.6 months $(95 \% \mathrm{CI}=2.7-6.3)$ and 3.3 months $(95 \% \mathrm{CI}=2.7-4.7)$ in the $\mathrm{KRAS}^{+}$and non-KRAS subgroups, respectively $(p=0.58)$. No significant difference in terms of OS was observed between the two subgroups. The mOS was 13.0 months (5.4-not estimable) and 8.1 months (6.1-15.3) in the $\mathrm{KRAS}^{+}$and nonKRAS subgroup respectively $(p=0.38)$, Figure 1B. At univariate analysis, no statistically significant differences were found in terms of PFS $(p=0.39)$ or OS $(p=0.78)$ between patients treated in first-line setting and those treated in the following lines (Table III). All risk factors found to have a $p<0.05$ at univariate analysis for OS were included as covariates in the multivariable model. At the multivariable analysis, ECOG PS 2 remained significantly associated with a higher risk of death $(\mathrm{HR}=3.14,95 \% \mathrm{CI}=1.42-6.92 ; p=0.005)$. At univariate analysis, ECOG P2 2 was the only factor significantly associated with an increased risk for progressive disease $(\mathrm{HR}=2.43,95 \% \mathrm{CI}=1.22-4.84 ; p=0.01)$, confirmed at multivariable $\quad(\mathrm{HR}=2.40,95 \% \quad \mathrm{CI}=1.22-4.73 ; \quad p=0.01)$. Regarding efficacy of IO with respect to PD-L1 expression in KRAS mutated population, PFS and OS were not significantly different in negative patients (PD-L1 TPS $<1 \%$ ) versus positive (PD-L1 $\geq 1 \%$ ). The same results were obtained by splitting the population into three groups: PD-L1 TPS $<1 \%$, between $1 \%$ and $49 \%$ and $\geq 50 \%$. No statistically significant difference was observed in terms of $\mathrm{OS}(\mathrm{HR}=1.11,95 \% \mathrm{CI}=0.57-2.15 ; p=0.76)$ or PFS (HR 1.03, 95\%CI 0.59-1.81; $p=0.91$ ) when patents with $\mathrm{G} 12 \mathrm{C}$ were compared to other mutation subtypes. 
Table I. Patient characteristics and demographics.

\begin{tabular}{|c|c|c|c|c|}
\hline Characteristic & Levels & Non-KRAS $(\mathrm{N}=117)$ & $\mathrm{KRAS}^{+}(\mathrm{N}=43)$ & $p$-Value \\
\hline Median f.u. time, months & & 15.4 & 18.5 & 0.81 \\
\hline \multirow[t]{2}{*}{ Age, years } & At diagnosis & $64(56-71)$ & $61(54-68)$ & 0.12 \\
\hline & At IO start & $65(59-72)$ & $62(55-68)$ & 0.06 \\
\hline \multirow{2}{*}{ Gender } & Female & $39(33.3)$ & $21(48.8)$ & \\
\hline & Male & $78(66.7)$ & $22(51.2)$ & 0.10 \\
\hline \multirow[t]{5}{*}{ Type of metastases } & Bone & $42(35.9)$ & $17(39.5)$ & 0.71 \\
\hline & Brain & $18(15.4)$ & $13(30.2)$ & 0.04 \\
\hline & Liver & $13(11.1)$ & $7(16.3)$ & 0.42 \\
\hline & Visceral & $18(15.4)$ & $15(34.9)$ & 0.014 \\
\hline & Other sites & $89(76.1)$ & $37(86.1)$ & 0.20 \\
\hline \multirow[t]{3}{*}{ No. of metastases sites per patient } & 1 & $58(49.5)$ & $9(20.9)$ & \\
\hline & 2 & $43(36.8)$ & $19(44.2)$ & \\
\hline & [3-5] & $16(13.7)$ & $15(34.9)$ & $<0.001$ \\
\hline \multirow[t]{3}{*}{ No. of comorbidities } & 0 & 0 & $3(7.0)$ & \\
\hline & 1 & $107(91.5)$ & $31(72.1)$ & \\
\hline & {$[2-3]$} & $10(8.5)$ & $9(20.9)$ & 0.001 \\
\hline \multirow[t]{6}{*}{ Comorbidities } & No comorbidities & 0 & $3(7.0)$ & \\
\hline & CPDO & $7(6.0)$ & $5(11.6)$ & 0.31 \\
\hline & Auto-immune disorders & $2(1.7)$ & $3(7.0)$ & 0.25 \\
\hline & Lung interstitial disease & 0 & $1(2.3)$ & 0.47 \\
\hline & $\mathrm{HCV} / \mathrm{HBV}$ & $1(0.9)$ & $2(4.7)$ & 0.18 \\
\hline & Other & $117(100)$ & $40(93.0)$ & 0.018 \\
\hline \multirow[t]{2}{*}{ ECOG PS } & $0-1$ & $112(95.7)$ & $38(88.4)$ & \\
\hline & 2 & $5(4.3)$ & $5(11.6)$ & 0.13 \\
\hline \multirow[t]{2}{*}{ Smoking habitus } & Former/Current & $91(77.8)$ & $40(93.0)$ & \\
\hline & Never & $26(22.2)$ & $3(7.0)$ & 0.04 \\
\hline \multirow[t]{4}{*}{ Stage at diagnosis } & IA & $3(2.6)$ & $1(2.3)$ & \\
\hline & IIB-IIIA-IIIB & $31(26.5)$ & $13(30.2)$ & \\
\hline & IB & $5(4.3)$ & 0 & \\
\hline & IV & $78(66.7)$ & $29(67.4)$ & 0.80 \\
\hline \multirow[t]{7}{*}{ PD-L1 status ${ }^{\mathrm{a}}$} & Positive & $59(50.4)$ & $30(69.8)$ & \\
\hline & Negative & $5(4.3)$ & $7(16.3)$ & \\
\hline & Missing & $53(45.3)$ & $6(14.0)$ & $<0.001$ \\
\hline & $<1 \%$ & $5(4.3)$ & $7(16.3)$ & \\
\hline & {$[1-49 \%]$} & $19(16.2)$ & $19(23.3)$ & \\
\hline & $\geq 50 \%$ & $40(34.2)$ & $20(46.5)$ & \\
\hline & Missing & $53(45.3)$ & $6(14.0)$ & $<0.001$ \\
\hline \multirow[t]{8}{*}{ Setting } & I & $30(25.6)$ & $14(32.6)$ & \\
\hline & II & $56(47.9)$ & $14(32.6)$ & \\
\hline & III & $23(19.7)$ & $12(27.9)$ & \\
\hline & IV & $6(5.1)$ & $2(4.7)$ & \\
\hline & $\mathrm{V}$ & $1(0.9)$ & $1(2.3)$ & \\
\hline & VII & $1(0.9)$ & 0 & 0.43 \\
\hline & I & $30(25.6)$ & $14(32.6)$ & \\
\hline & II-VII & 87 (74.4) & $29(67.4)$ & 0.43 \\
\hline Co-mutation & & - & $10(23.3)$ & \\
\hline
\end{tabular}

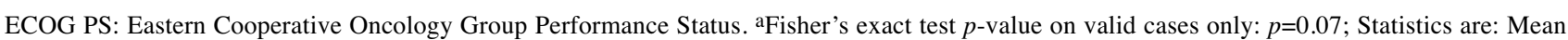
(IQR) for age, $\mathrm{N}$ (column \%) for all other variables except follow-up time (median); Median follow-up time for all patients is 16.8 months; minimum age at IO therapy start is 43 years ( 1 mutated subject) and maximum 84 years ( 1 non-mutated subject); all patients had at least one metastatic site involvement; all patients were HIV-negative.

\section{Discussion}

This is a mono-Institutional retrospective analysis of $\mathrm{KRAS}^{+}$ NSCLC patients treated with IO. We compared the results with a non-matched KRAS negative patient population. We did not record any difference according to PFS and OS. At univariate and multivariate analyses, ECOG PS 2 was the solely negative predictive factor associated with worse outcomes. To date, despite the novel small molecule AMG 510 has shown promising results in KRAS G12C mutant NSCLC (17), no 


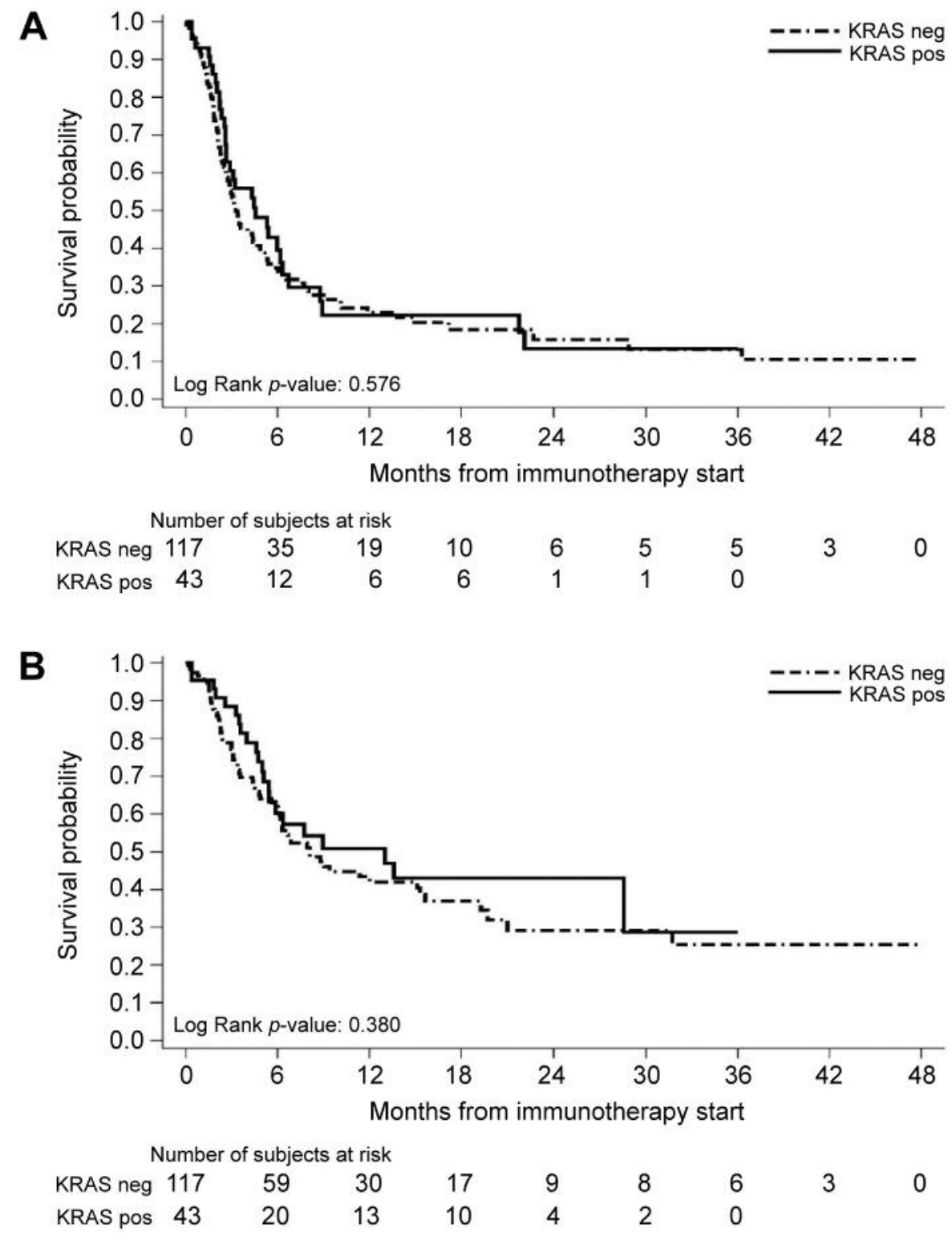

Figure 1. Kaplan-Meier curves for progression-free survival (A) and overall survival (B) according to KRAS status.

approved therapy targets KRAS. The recent introduction of immunotherapy represents a paradigm shift in the treatment of NSCLC, but is unclear whether the presence of an actionable mutation could affect the clinical outcome of IO. Data from meta-analyses have shown that patients with EGFR or ALKpositive NSCLC do not benefit from IO, at least when administered alone (18-20). Data about other driver genes are more questionable. To date, two meta-analyses demonstrated that KRAS mutation status did not affect negatively survival outcome of IO in patients with advanced $\operatorname{NSCLC}(18,21)$. Retrospective data suggested that KRAS status did not influence IO efficacy (22-24). Furthermore, Mazieres et al. (9)
Table II. Best response rate assessment by KRAS status.

\begin{tabular}{lccc}
\hline Best response & $\begin{array}{c}\text { Non-KRAS } \\
(\mathrm{N}=88)\end{array}$ & $\begin{array}{c}\mathrm{KRAS}^{+} \\
(\mathrm{N}=41)\end{array}$ & $p$-Value \\
\hline CR & $3(3.4)$ & 0 & - \\
PR & $29(33.0)$ & $8(19.5)$ & - \\
SD & $17(19.3)$ & $14(34.1)$ & - \\
PD & $39(44.3)$ & $19(46.3)$ & - \\
ORR & $32(36.4)$ & $8(19.5)$ & 0.07 \\
DCR & $49(55.7)$ & $22(53.7)$ & 0.85 \\
\hline
\end{tabular}

ORR: Objective response rate $(\mathrm{CR}+\mathrm{PR})$; $\mathrm{DCR}$ : disease control rate $(\mathrm{CR}+\mathrm{PR}+\mathrm{SD})$. Statistics are: N (column \%) of best response assessable

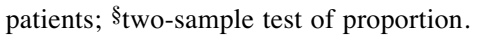


Table III. Progression-free survival (PFS) and overall survival (OS) univariate analyses.

\begin{tabular}{|c|c|c|c|c|c|}
\hline \multirow[b]{2}{*}{ Characteristic } & & \multicolumn{2}{|c|}{ PFS } & \multicolumn{2}{|c|}{ OS } \\
\hline & & $\operatorname{HR}(95 \% \mathrm{CI})^{\mathrm{a}}$ & $p$-Value ${ }^{b}$ & $\operatorname{HR}(95 \% \mathrm{CI})^{\mathrm{a}}$ & $p$-Value ${ }^{b}$ \\
\hline \multirow[t]{2}{*}{ KRAS } & Non-KRAS & 1.00 & & 1.00 & \\
\hline & $\mathrm{KRAS}^{+}$ & $0.89(0.59-1.34)$ & 0.58 & $0.81(0.50-1.31)$ & 0.38 \\
\hline \multirow[t]{2}{*}{ Gender } & Male & 1.00 & & 1.00 & \\
\hline & Female & $1.07(0.74-1.54)$ & 0.71 & $0.99(0.65-1.52)$ & 0.98 \\
\hline \multirow[t]{6}{*}{ Type of metastases } & Brain & & & & \\
\hline & No & 1.00 & & 1.00 & \\
\hline & Yes & $1.46(0.94-2.28)$ & 0.09 & $1.39(0.83-2.34)$ & 0.21 \\
\hline & Visceral & & & & \\
\hline & No & 1.00 & & 1.00 & \\
\hline & Yes & $1.07(0.69-1.66)$ & 0.76 & $1.07(0.63-1.79)$ & 0.81 \\
\hline \multirow{3}{*}{$\begin{array}{l}\text { No. of metastases sites } \\
\text { per patient }\end{array}$} & 1 & 1.00 & & 1.00 & \\
\hline & 2 & $1.03(0.69-1.54)$ & 0.88 & $0.98(0.61-1.56)$ & 0.93 \\
\hline & {$[3-5]$} & $1.27(0.77-2.10)$ & 0.34 & $1.28(0.71-2.31)$ & 0.41 \\
\hline \multirow[t]{3}{*}{ No. of comorbidities } & 0 & 1.00 & & 1.00 & \\
\hline & 1 & $1.24(0.39-3.93)$ & 0.71 & $1.21(0.42-21.9)$ & 0.27 \\
\hline & {$[2-3]$} & $1.30(0.37-4.53)$ & 0.68 & $1.24(0.41-24.8)$ & 0.27 \\
\hline \multirow[t]{2}{*}{ ECOG PS } & $0-1$ & 1.00 & & 1.00 & \\
\hline & 2 & $1.87(0.91-3.87)$ & 0.09 & $3.00(1.37-6.61)$ & 0.006 \\
\hline \multirow[t]{2}{*}{ Smoking habitus } & Never & 1.00 & & 1.00 & \\
\hline & Former/Current & $1.39(0.90-2.17)$ & 0.14 & $1.22(0.73-2.02)$ & 0.45 \\
\hline \multirow[t]{3}{*}{ PDL1 Status } & Positive & 1.00 & & 1.00 & \\
\hline & Negative & $1.01(0.52-1.97)$ & 0.98 & $1.02(0.48-2.17)$ & 0.97 \\
\hline & Missing & $0.98(0.67-1.45)$ & 0.94 & $1.19(0.76-1.87)$ & 0.44 \\
\hline \multirow[t]{2}{*}{ Setting } & I & 1.00 & & 1.00 & \\
\hline & II-VII & $0.94(0.63-1.43)$ & 0.78 & $1.26(0.75-2.12)$ & 0.39 \\
\hline \multirow[t]{2}{*}{ Prednisolone $e^{\S}$} & Yes & 1.00 & & 1.00 & \\
\hline & No & $0.73(0.51-1.05)$ & 0.09 & $0.71(0.47-1.08)$ & 0.11 \\
\hline Age at IO start, years & & $1.00 \mathrm{c}(0.98-1.01)$ & 0.58 & $1.00 \mathrm{c}(0.98-1.02)$ & 0.98 \\
\hline
\end{tabular}

ECOG PS: Eastern Cooperative Oncology Group Performance Status. ${ }^{a, b}$ Hazard ratio with 95\% CI and $p$-values obtained from Cox regression model; cby 1-year increase; ${ }^{\circledR}$ Concomitant $<10 \mathrm{mg} / \mathrm{d}$ prednisolone eq $/>10 \mathrm{mg}$.

retrospectively collected data of $271 \mathrm{KRAS}^{+}$NSCLC patients receiving IO and confirmed that KRAS did not negatively affect the outcome of IO. Trying to understand the biology background, Skoulidis et al. identified an "immune cold" group $\left(\mathrm{KRAS}^{+} / \mathrm{SKT} 11 / \mathrm{LKB} 1+\right)$ with a worse outcome when treated with IO, characterized by lower expression levels of immune markers, including PD-L1, inactivate T cell infiltration and high levels of myeloid-recruiting chemokines (25). We analyzed $43 \mathrm{KRAS}^{+}$NSCLC patients, of them 10 had comutation and most patients had G12C. Due to the low sample number of patients, we failed to demonstrate any correlation among co-mutation or subtype KRAS mutation and clinical outcome. Regarding the efficacy of IO in $\mathrm{KRAS}^{+}$patients with respect to PD-L1 expression, PFS and OS were not significantly different in negative cases (PD-L1 TPS $<1 \%) v s$. positive (PDL1 $\geq 1 \%$ ) nor in patients with PD-L1 TPS $<1 \%$ vs. $1-49 \%$ vs. $\geq 50 \%$. These results could be related to the fact that KRAS mutation induces PD-L1 overexpression through activation of its downstream pathways: MAPK signaling could represent the dominant downstream signal responsible for ectopic PD-L1 expression and KRAS-mediated up-regulation of PD-L1 could induce the apoptosis of $\mathrm{CD}^{+} \mathrm{T}$ cells and mediate immune escape (26-27). In our study, ECOG PS 2 emerges as the sole factor associated with a higher risk of death and with an increased risk for progressive disease at multivariable analysis. This suggests that also in $\mathrm{KRAS}^{+}$ patients, the use of immunotherapy in ECOG PS2 patients should be carefully considered. In fact, taking into account the heterogeneity of ECOG PS2 population and the lack of robust data derived from the exclusion of PS 2 patients from the majority of IO trials (28), the decision of treating with IO $\mathrm{KRAS}^{+}$fragile patients, should be discussed case by case. Despite the retrospective nature of our study, which implies other limitation like reporting bias (e.g., single institution, putative selection of good prognosis patient, high prevalence of strong expression of PD-L1, non-matched control group), our data could be of interest. Our retrospective study conducted on 160 NSCLC patients treated with IO, showed 
that the efficacy of immunotherapy in terms of response rate and survival outcomes was comparable in patients with or without KRAS. Therefore, in clinical practice, IO should be considered as an effective therapy for NSCLC patients, regardless of KRAS status.

\section{Conflicts of Interest}

The Authors declare no conflicts of interest regarding this study.

\section{Authors' Contributions}

LG, GS and AP designed the study and contributed primarily in writing of the manuscript, DR provided statistical analysis, CF and EG performed molecular analysis and PDL1 evaluation, DR, FdM and MB performed a critical revision of article, all the other authors contributed in the collection of data, completion of study, and reviewing the writing of the manuscript. All listed Authors declare consent to the article's publication.

\section{References}

1 Riely GJ, Marks J and Pao W: KRAS mutations in non-small cell lung cancer. Proc Am Thorac Soc 6: 201-205, 2009. PMID: 19349489. DOI: $10.1513 /$ pats.200809-107LC

2 Passaro A, Palazzo A, Trenta P, Mancini ML, Morano F and Cortesi E: Molecular and clinical analysis of predictive biomarkers in non-small-cell lung cancer. Curr Med Chem 19(22): 3689-3700, 2012. PMID: 22680928. DOI: 10.2174/ 092986712801661149

3 Linardou H, Kotoula V, Kouvatseas G, Mountzios G, Karavasilis V, Samantas E, Kalogera-Fountzila A, Televantou D, Papadopoulou K, Mavropoulou X, Daskalaki E, Zaramboukas T, Efstratiou I, Lampaki S, Rallis G, Res E, Syrigos KN, Kosmidis PA, Pectasides D and Fountzilas G: Genotyping KRAS and EGFR mutations in Greek patients with non-small-cell lung cancer: Incidence, significance and implications for treatment. Cancer Genomics Proteomics 16(6): 531-541, 2019. PMID: 31659106. DOI: $10.21873 / \operatorname{cgp} .20155$

4 Planchard D, Popat S, Kerr K, Novello S, Smit EF, Faivre-Finn C, Mok TS, Reck M, Van Schil PE, Hellmann MD and Peters S: Metastatic non-small cell lung cancer: ESMO Clinical Practice Guidelines for diagnosis, treatment and follow-up. Ann Oncol 29(4): iv192-iv237, 2018. PMID: 30715168. DOI: 10.1093/ annonc/mdy 474

5 Doroshow DB, Sanmamed MF, Hastings K, Politi K, Rimm DL, Chen L, Melero I, Schalper KA and Herbst RS: Immunotherapy in Non-Small Cell Lung Cancer: Facts and Hopes. Clin Cancer Res 25(15): 4592-4602, 2019. PMID: 30824587. DOI: 10.1158/1078-0432.CCR-18-1538

6 Camidge DR, Doebele RC and Kerr KM: Comparing and contrasting predictive biomarkers for immunotherapy and targeted therapy of NSCLC. Nat Rev Clin Oncol 16(6): 341-355, 2019. PMID: 30718843. DOI: 10.1038/s41571-019-0173-9

7 Bianco A, Perrotta F, Barra G, Malapelle U, Rocco D and De Palma R: Prognostic factors and biomarkers of responses to immune checkpoint inhibitors in lung cancer. Int J Mol Sci 20(19): E4931, 2019. PMID: 31590386. DOI: 10.3390/ijms20194931
8 Ando C, Ichihara E, Kano H, Iwamoto Y, Hirabae A, Nakasuka T, Maeda Y and Kiura K: Granulation tissue-induced pseudorelapse during nivolumab treatment in advanced non-small cell lung cancer. In Vivo 33(6): 2113-2115, 2019. PMID: 31662545. DOI: 10.21873 /invivo.11711

9 Mazières J, Drilon A, Lusque A, Mhanna L, Cortot AB, Mezquita L, Thai AA, Mascaux C, Couraud S, Veillon R, Van Den Heuvel M, Neal J, Peled N, Früh M, Ng TL, Gounant V, Popat S, Diebold J, Sabari J, Zhu VW, Rothschild SI, Bironzo P, Martinez A, Curioni-Fontecedro A, Rosell R, Lattuca-Truc M, Wiesweg M, Besse B, Solomon B, Barlesi F, Schouten RD, Wakelee H, Camidge DR, Zalcman G, Novello S, Ou SI, Milia J and Gautschi O: Immune checkpoint inhibitors for patients with advanced lung cancer and oncogenic driver alterations: results from the IMMUNOTARGET registry. Ann Oncol 30(8): 13211328, 2019. PMID: 31125062. DOI: 10.1093/annonc/mdz167

10 Borghaei H, Paz-Ares L, Horn L, Spigel DR, Steins M, Ready NE, Chow LQ, Vokes EE, Felip E, Holgado E, Barlesi F, Kohlhäufl M, Arrieta O, Burgio MA, Fayette J, Lena H, Poddubskaya E, Gerber DE, Gettinger SN, Rudin CM, Rizvi N, Crinò L, Blumenschein GR Jr, Antonia SJ, Dorange C, Harbison $\mathrm{CT}$, Graf Finckenstein F and Brahmer JR: Nivolumab versus docetaxel in advanced nonsquamous non-small-cell lung cancer. N Engl J Med 373(17): 1627-1639, 2015. PMID: 26412456. DOI: 10.1056/NEJMoa1507643

11 Rittmeyer A, Barlesi F, Waterkamp D, Park K, Ciardiello F, von Pawel J, Gadgeel SM, Hida T, Kowalski DM, Dols MC, Cortinovis DL, Leach J, Polikoff J, Barrios C, Kabbinavar F, Frontera OA, De Marinis F, Turna H, Lee JS, Ballinger M, Kowanetz M, He P, Chen DS, Sandler A and Gandara DR: Atezolizumab versus docetaxel in patients with previously treated non-small-cell lung cancer (OAK): a phase 3, open label, multicentre randomised controlled trial. Lancet 389(10066): 255-265, 2017. PMID: 27979383. DOI: 10.1016/S0140-6736(16)32517-X

12 Fehrenbacher L, Spira A, Ballinger M, Kowanetz M, Vansteenkiste J, Mazieres J, Park K, Smith D, Artal-Cortes A, Lewanski C, Braiteh F, Waterkamp D, He P, Zou W, Chen DS, Yi J, Sandler A and Rittmeyer A: Atezolizumab versus docetaxel for patients with previously treated non-small-cell lung cancer (POPLAR): a multicentre, open-label, phase 2 randomised controlled trial. Lancet 387(10030): 1837-1846, 2016. PMID: 26970723. DOI: 10.1016/S0140-6736(16)00587-0

13 Socinski MA, Jotte RM, Cappuzzo F, Orlandi F, Stroyakovskiy D, Nogami N, Rodríguez-Abreu D, Moro-Sibilot D, Thomas CA, Barlesi F, Finley G, Kelsch C, Lee A, Coleman S, Deng Y, Shen Y, Kowanetz M, Lopez-Chavez A, Sandler A and Reck M: Atezolizumab for first-line treatment of metastatic nonsquamous NSCLC. N Engl J Med 378 (24): 2288-2301, 2018. PMID: 29863955. DOI: 10.1056/NEJMoa 1716948

14 Casadio C, Guarize J, Donghi S, Di Tonno C, Fumagalli C, Vacirca D, Dell'Orto P, De Marinis F, Spaggiari L, Viale G and Barberis M: Molecular testing for targeted therapy in advanced non-small cell lung cancer: Suitability of endobronchial ultrasound transbronchial needle aspiration. Am J Clin Pathol 144(4): 629-634, 2015. PMID: 26386084. DOI: 10.1309/AJCPXGRAIMB4CTQ3

15 Fumagalli C, Vacirca D, Rappa A, Passaro A, Guarize J, Rafaniello Raviele P, de Marinis F, Spaggiari L, Casadio C, Viale G, Barberis $M$ and Guerini-Rocco E: The long tail of molecular alterations in non-small cell lung cancer: a singleinstitution experience of next-generation sequencing in clinical 
molecular diagnostics. J Clin Pathol 71(9): 767-773, 2018 PMID: 29535211. DOI: 10.1136/jclinpath-2018-205032

16 Marchetti A, Barberis M, Franco R, De Luca G, Pace MV, Staibano S, Volante M, Buttitta F, Guerini-Rocco E, Righi L, D'antuono T, Scagliotti GV, Pinto C, De Rosa G and Papotti M: Multicenter comparison of 22C3 PharmDx (Agilent) and SP263 (Ventana) assays to test PD-L1 expression for NSCLC patients to be treated with immune checkpoint inhibitors. J Thorac Oncol 12(11): 1654-1663, 2017. PMID: 28818609. DOI: $10.1016 /$ j.jtho.2017.07.031

17 Govindan R, Fakih M, Price T, Falchook G, Desai J, Kuo J, Strickler J, Krauss J, Li B, Denlinger C, Durm G, Ngang J, Henary H, Ngarmchamnanrith G, Rasmussen E, Morrow P and Hong D: Phase 1 study of safety, tolerability, PK and efficacy of AMG 510, a novel KRAS G12C inhibitor, evaluated in NSCLC. J Thorac Oncol 14(suppl): Abstr OA02.02, 2019. DOI: 10.1200/JCO.2019.37.15_suppl.3003

18 Lee CK, Man J, Lord S, Links M, Gebski V, Mok T and Yang JC: Checkpoint inhibitors in metastatic EGFR-Mutated non-small cell lung cancer - A meta-analysis. J Thoracic Onc 12(2): 403-407, 2016. PMID: 27765535. DOI: 10.1016/j.jtho.2016.10.007

19 Lee CK, Man J, Lord S, Cooper W, Links M, Gebski V, Herbst RS, Gralla RJ, Mok $\mathrm{T}$ and Yang JC: Clinical and molecular characteristics associated with survival among patients treated with checkpoint inhibitors for advanced non-small cell lung carcinoma: A systematic review and meta-analysis. JAMA Oncol 4(2): 210216, 2018. PMID: 29270615. DOI: 10.1001/jamaoncol.2017.4427

20 Agyeman AS, Vallejo JJ, Myers A and Blumenthal GM: Metaanalysis exploring the effect of oncogenic driver mutations on outcome of metastatic Non-small cell Lung cancer patients treated with immune checkpoint inhibitors or docetaxel. J Clin Oncol 36(15_suppl): 9029, 2018. DOI: 10.1200/JCO.2018.36.15_suppl. 9029

$21 \mathrm{Kim} \mathrm{JH}$, Kim HS and Kim BJ: Prognostic value of KRAS mutation in advanced non-small-cell lung cancer treated with immune checkpoint inhibitors: A meta-analysis and review. Oncotarget 8(29): 48248-48252, 2017. PMID: 28525386. DOI: 10.18632/oncotarget.17594

22 Passiglia F, Cappuzzo F, Alabiso O, Bettini AC, Bidoli P, Chiari R, Defferrari C, Delmonte A, Finocchiaro G, Francini G, Gelsomino F, Giannarelli D, Giordano M, Illiano A, Livi L, Martelli O, Natoli C, Puppo G, Ricevuto E, Roca E, Turci D and Galetta D: Efficacy of nivolumab in pre-treated non-small-cell lung cancer patients harbouring KRAS mutations. Br J Cancer 120(1): 57-62, 2019. PMID: 30377342. DOI: 10.1038/s41416018-0234-3
23 Jeanson A, Tomasini P, Souquet-Bressand M, Brandone N, Boucekine M, Grangeon M, Chaleat S, Khobta N, Milia J, Mhanna L, Greillier L, Biemar J, Nanni I, Ouafik L, Garcia S, Mazières J, Barlesi F and Mascaux C: Efficacy of immune checkpoint inhibitors in KRAS-mutant non-small cell lung cancer (NSCLC). J Thorac Oncol 14(6): 1095-1101, 2019. PMID: 30738221. DOI: 10.1016/j.jtho.2019.01.011

24 Torralvo J, Friedlaender A, Achard V and Addeo A: The activity of immune checkpoint inhibition in KRAS mutated non-small cell lung cancer: a single centre experience. Cancer Genomics Proteomics 16(6): 577-582, 2019. PMID: 31659111. DOI: $10.21873 / \operatorname{cgp} .20160$

25 Skoulidis F, Byers LA, Diao L, Papadimitrakopoulou VA, Tong P, Izzo J, Behrens C, Kadara H, Parra ER, Canales JR, Zhang J, Giri U, Gudikote J, Cortez MA, Yang C, Fan Y, Peyton M, Girard L, Coombes KR, Toniatti C, Heffernan TP, Choi M, Frampton GM, Miller V, Weinstein JN, Herbst RS, Wong KK, Zhang J, Sharma P, Mills GB, Hong WK, Minna JD, Allison JP, Futreal A, Wang J, Wistuba II and Heymach JV: Co-occurring genomic alterations define major subsets of KRAS-mutant lung adenocarcinoma with distinct biology, immune profiles, and therapeutic vulnerabilities. Cancer Discov 5(8): 860-877, 2015. PMID: 26069186. DOI: 10.1158/2159-8290.CD-14-1236

26 Sumimoto H, Takano A, Teramoto K and Daigo Y: Ras-mitogenactivated protein kinase signal is required for enhanced PD-L1 expression in human lung cancers. PLoS One 11(11): e0166626, 2016. PMID: 27846317. DOI: 10.1371/journal.pone.0166626

27 Chen N, Fang W, Lin Z, Peng P, Wang J, Zhan J, Hong S, Huang J, Liu L, Sheng J, Zhou T, Chen Y, Zhang H and Zhang L: KRAS mutation-induced upregulation of PD-L1 mediates immune escape in human lung adenocarcinoma. Cancer Immunol Immunother 66(9): 1175-1187, 2017. PMID: 28451792. DOI: $10.1007 / \mathrm{s} 00262-017-2005-\mathrm{z}$

28 Passaro A, Spitaleri G, Gyawali B and de Marinis F: Immunotherapy in non-small-cell lung cancer patients with performance status 2: clinical decision making with scant evidence. J Clin Oncol 37(22): 1863-1867. PMID: 30995172. DOI: $10.1200 / J C O .18 .02118$
Received November 1, 2019

Revised November 14, 2019

Accepted November 18, 2019 